Universidad de Lima

Facultad de Derecho

Carrera de Derecho

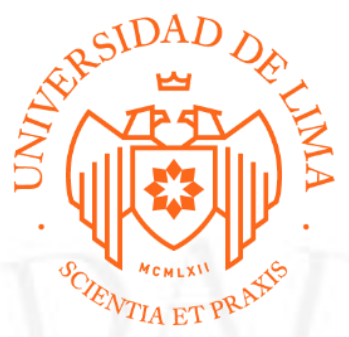

\title{
CIVIL: "OTORGAMIENTO DE ESCRITURA PÚBLICA" Y ADMINISTRATIVO: "ACCIÓN CONTENCIOSO ADMINISTRATIVO"
}

Trabajo de suficiencia profesional para optar el Título Profesional de Abogada

\author{
Karinna Elvira Vásquez Castro
}

Código 20101173

Lima - Perú

Junio de 2019 
Materia: Otorgamiento de Escritura Pública Número de Expediente: 12907-2010-0-1801-JR-CI-26

Materia: Acción Contencioso Administrativa

Número de Expediente: 00721-2013-0-0401-JR-LA-05 